Rojas (2018)

\title{
ANSERJ
}

Vol. 9, No. 2

Autumn / Automne 2018

pp. $62-79$

Canadian Journal of Nonprofit and Social Economy Research

Revue canadienne de recherche sur les OBSL et l'économie social

\section{The Competitive Edge of Credit Unions in Costa Rica: From Financial Repression to the Risks of a New Financial Environment}

\author{
Miguel Rojas \& Sébastien Deschênes \\ Université de Moncton \\ Lovasoa Ramboarisata \\ Université du Québec à Montréal
}

André Leclerc

Université de Moncton

\begin{abstract}
This article argues that financial repression played a key role in the emergence of credit unions (CUs) in Costa Rica, along with other institutional factors. Credit unions took advantage of the opportunity to serve borrowers whose requests had been refused by banks. Given the sweeping reforms of the Costa Rican financial system aimed at reducing the scope of financial repression, this article poses the question of how those reforms impacted the competitiveness of CUs. Previous literature suggests that financial reform may lead to concentration in the financial sector, and not to the promotion of a more competitive environment. This article presents data showing that CUs in Costa Rica exhibited an enhanced ability to gain market share and also provides an explanation for the observed trend.
\end{abstract}

\section{RÉSUMÉ}

L'article soutient que la répression financière avec d'autres facteurs institutionnels a joué un rôle clé dans l'émergence des coopératives financières (CF) au Costa Rica. Les CF ont profité de l'occasion pour servir les emprunteurs dont les demandes avaient été refusées par les banques. Compte tenu des réformes radicales du système financier costaricien, visant à réduire l'étendue de la répression financière, l'article pose la question de l'incidence de ces réformes sur la compétitivité des CF. La littérature précédente suggère que la réforme financière peut conduire à une concentration du secteur financier et non à la promotion d'un environnement plus compétitif. Notre article démontre que les CF du Costa Rica présentent une capacité à accroître leurs parts de marché. Nous fournissons une explication de la tendance observée.

KEYWORDS / MOTS CLÉS Financial markets; Government policy and regulation; Credit unions; Financial repression; Financial reform in developing countries; Costa Rica / Marchés financiers; Politiques et règlementations gouvernementales; coopératives financières; Répression financière; Reforme financière dans des pays en développement; Costa Rica 


\section{Rojas, Deschênes, Ramboarisata, \& Leclerc (2018)}

\section{INTRODUCTION}

During the 1980s, many developing countries started to dismantle policies that constrained the financial sector. Those earlier policies had been adopted in order to channel resources into the sectors of the economy deemed by economic authorities to be key for economic development. During the 1960s and 1970s, negative interest rates in real terms were widespread in the developing world, leading to the adoption of credit rationing that was not based on interest rates, such as setting caps on loans for a number of sectors and activities (Adams, 1971; McKinnon, 1973). Some agents in the economy benefited from subsidized credit, although this type of credit tended to accrue to a limited number of well-connected debtors. Ronald McKinnon (1973) criticized these policies as leading to what he called a fragmented economy, in which firms and households face different effective prices for the factors of production and do not have access to the same technologies. Eduardo Lizano (2004) contends that such measures of governmental intervention in financial markets, falling under the term financial repression actually harmed, rather than promoted, the prospects of economic development in the countries that adopted them.

In Costa Rica, these types of constraints on the financial sector were compounded by the nationalization of commercial banks that took place in 1948, a move aimed precisely at enhancing state control of interest rates and credit allocation (Camacho Mejia \& González-Vega, 1994). In 1948, a civil war took place in Costa Rica, which Cynthia Franklin (1998) contends is the starting point of democracy there. The victors in the civil war assured free and fair elections. The nationalization of the banks was one of the first measures undertaken by the junta that assumed power after the end of the civil war. The new authorities implemented policies aimed at the modernization of the country's economic systems and the creation of a welfare state (Sandbrook, Edelman, Heller, \& Teichman, 2007). A new political constitution was approved in 1949, which enshrined the government's obligation to promote cooperative organizations (Huaylupo Alcázar, 2003; Sánchez Boza \& Mayorga Acuña, 1988).

In Costa Rica, the Central Bank (Guardia, personal communication, 2015) systematically capped financing for consumption by individuals, so as to make room for sectors that government officials considered to be a priority, or simply for those sectors enjoying political clout. This article argues that, to some extent, a number of individuals managed to circumvent this aspect of financial repression in Costa Rica by joining credit unions (CUs), in order to obtain credit. These organizations were not subject to the restrictions imposed on the state-owned commercial banks that comprised most of the formal Costa Rican financial system at the time. Thus, financial repression was arguably an important driver of the growth of credit unions in Costa Rica during the 1960s and the 1970s. As discussed below, many of the existing CUs were established during this period. These players in the financial market saw an opportunity to serve borrowers that were routinely refused access to credit because banks had attained the cap established by authorities for lending to individuals for consumption.

From the mid-1980s to the mid-1990s, a vast reform of financial markets took place in Costa Rica (Lizano, 2004). Among other things, the private sector was allowed to establish banks; the state monopoly on chequing accounts was terminated, as was the authority of the central bank to enact quantitative controls on bank portfolios (caps) and on the interest rates charged by the state-owned banks (Cerdas \& Melegatti, 2014). Moreover, a new regulatory agency with enhanced powers and autonomy was established (García Soto, 2004).

The removal of financial repression (or at least of its most noticeable traits) that arguably had encouraged the emergence of CUs in Costa Rica must certainly have had an impact on their growth. This impact, however, could not have easily been predicted a priori. It could, for instance, have enhanced the ability of state-owned banks to compete for the CUs' clientele, once the quantitative controls on portfolios and interest rates had been removed, leading to a negative impact 


\section{Rojas, Deschênes, Ramboarisata, \& Leclerc (2018)}

on CUs' growth. Moreover, CUs are much smaller than state-owned commercial banks in Costa Rica, which might have diminished their capacity to compete with larger banks that could benefit from economies of scale. David Wheelock and Paul Wilson (2011) report that technological and regulatory changes in the United States appear to have favoured larger institutions. Information technologies, in particular, exhibit a tendency to favour large players because those technologies can be costly in terms of equipment and software and can reduce the competitive advantage of proximity to lenders that characterized the CUs.

The above-mentioned threats against the ability of CUs to remain competitive were compounded by another obvious menace, the entrance of a new type of actor into the financial sector, namely, private-sector banks. However, other aspects of the sweeping reforms implemented after the mid-1980s could have favoured the CUs' competitive advantage, and therefore, their growth. For instance, since CUs could not rely on state finances in case of bankruptcies or crises of confidence in financial institutions by the public, the greater regulation of all financial players could have the effect of decreasing their risks and of increasing the trust of economic agents in CUs. Also, decades of financial repression could have inflicted damage on the inflation-adjusted value of the assets possessed by state-owned banks, impairing their capacity to profit from the new rules. Moreover, the fact that state-owned commercial banks were accustomed to managing rigid capped portfolios limited their ability to cater to the new industries that emerged in Costa Rica after the mid-1980s (González-Vega, 1990). In hindsight, the answer to the question of how the financial reforms in Costa Rica affected CUs ought to be empirical. No previous studies have been found on the issue of how reforms of the financial sector impacted CUs in Costa Rica.

This article could be of interest to policymakers, who would benefit from new knowledge concerning the impact of financial reform on CUs. Credit unions are reportedly an important source of financing for many people. Globally, more than 235 million people are members of a CU (World Council of Credit Unions, 2016). Credit unions are important even in a country with a highly developed financial system such as the United States, where they held some 10 percent of household deposits by 2011 (Wheelock \& Wilson, 2011). Credit unions are thus too important to be ignored. Measures to further financial reform, in Costa Rica or elsewhere, would be facilitated if there was scholarly evidence of a positive impact of financial reform on CUs. This article could also benefit Costa Rican CU managers who wish to identify potential sources of growth available to the organizations that they run as a result of the new regulatory environment of the financial markets.

The next section of this article reviews some aspects of the development of CUs in Costa Rica, as well as the liberalization of Costa Rican financial markets. The following section discusses data and the methodology of the study. Another section is devoted to the presentation and analysis of the results. The final section presents concluding comments and suggests avenues for future research.

\section{FINANCIAL REPRESSION, THE EMERGENCE OF CREDIT UNIONS IN COSTA RICA, AND THE LIBERALIZATION OF FINANCIAL MARKETS}

Costa Rican economic policy between 1950 and the late 1970s was strongly interventionist. This was the result of a development strategy that has been labelled as import-substitution industrialization (ISI) (Lizano, 2004). This strategy involved a set of economic policies that included the erection of a "wall" of tariffs on imports of manufactured products, so as to facilitate the substitution of imports by local production. ${ }^{1}$ Interventionism in the external-trade sector was mirrored in the financial markets by governmental policies intended to set quantitative controls for interest rates and credit allocation.

These policies included setting, on an annual basis, caps for the loan portfolios of commercial banks that were destined for the sectors of the economy considered a priority by the economic authorities of the country, and those sectors able to exert political pressure on governmental officers. These caps were presumably higher than the levels that those 


\section{Rojas, Deschênes, Ramboarisata, \& Leclerc (2018)}

activities would have attained in the presence of competitive markets. They were set by the Central Bank at a level that was compatible with inflation targets and the expansion of the monetary base (Guardia, personal communication, 2015; Lizano, personal communication, 2017).

The mechanics of capping bank-loan portfolios (topes de cartera in Spanish) were complex. Caps for around 50 economic activities were set each year. Credit to finance consumption by individuals was not considered a priority and, therefore, lower caps were set for it (Guardia, personal communication, 2015). Sectors attaining the caps could exert pressure on the Central Bank authorities to raise the cap, if they had the political power to do so (Lizano, personal communication, 2017). In practice, caps became a sort of "entitlement," and benefitted those sectors that could pressure for the caps of the preceding year to become the minimum that could be lent to them, even if the economic circumstances had changed (González-Vega, 1990). Negative real interest rates were common during this period (Adams, 1971), especially toward the end of the ISI-dominated period (Lizano, 2004). These types of constraints on the financial sector were compounded in Costa Rica by the nationalization of commercial banks, which took place in 1948, aimed precisely at enhancing state control of interest rates and credit allocation (Camacho Mejía \& González-Vega, 1994; Franklin, 1998). Lizano (2004) argues that the above-mentioned policies did more harm than good to the prospects of economic development in the countries that adopted them.

It is noteworthy that the decree of the nationalization of existing banks in 1948 did not declare the operation of private banks illegal. These banks, however, were not to engage in any financial intermediation because only the state-owned commercial banks had the privilege to issue chequing accounts and savings accounts (González-Vega, 1990). One private-sector bank (Banco Lyon) coexisted with state-owned commercial banks after 1948, but it did not constitute a serious competitor for them (Rojas Herrera, 1994). Commercial banks owned by the state controlled 99.1 percent of all assets owned by the banking industry (excluding CUs and other non-banking players) in Costa Rica in 1955, a figure that almost did not budge over the next 25 years (Rojas Herrera, 1994). By 1980, banks belonging to the state still owned 98.9 percent of all assets of the banking industry. In 1990 the corresponding figure was 87.3 percent, which gives an idea of the depth of the reforms, even in their early stages.

It was in the context of financial repression that most of the existing CUs in Costa Rica emerged, particularly the largest among them today. The appearance of such financial players was a collective response to a lack of credit for consumption that confronted a great number of individuals in Costa Rica during the 1950s and 1960s because of financial repression. Governmental intervention in the financial markets reduced credit for consumption, as already mentioned (Guardia, personal communication, 2015; Lizano, personal communication, 2017). This article asserts that credit unions took the opportunity to fill that gap, taking advantage of the absence of strong competition from state-owned banks, which were hampered by existing financial policies, and of the virtual absence of private-sector banks in the Costa Rican financial industry. This argument draws on previous literature. Individuals and groups that had to face the artificial scarcities of financing brought about by financial repression could be expected to find alternative ways to fund their investment and consumption projects. As McKinnon (1973) put it,

Bank credit remains a financial appendage of certain enclaves: exclusively licensed import activities, specialized large-scale mineral exports, highly protected manufacturing, large international corporations, and various government agencies, such as coffee marketing boards or publicly controlled utilities. ... Financing of the rest of the economy must be met from the meager resources of moneylenders, pawnbrokers, and cooperatives. It is this phenomenon that I call "financial repression." (pp. 68-69, emphasis added) 


\section{Rojas, Deschênes, Ramboarisata, \& Leclerc (2018)}

Sometimes the reaction of credit-starved actors could be more effective. For instance, Claudio González-Vega (1990) discusses the emergence during the 1960s and 1970s in Costa Rica of private-sector "financieras," financial entities that lent to the private sector and found loopholes to issue certificates of deposit to the public. By 1972 there were 51 "financieras," some 20 of which were formally regulated (González-Vega, 1990).

Most Costa Rican CUs were established during the period when financial repression was the norm in Costa Rica. Table 1 shows that 25 CUs out of the 29 regulated by the Superintendencia General de Entidades Financieras (SUGEF) by December 2013 were created during the years 1955-1979. Just four CUs were established during the 1980s and the 1990s. It is worth noting that none have been established since the year 2000.

\section{Table 1: Date of creation of credit unions regulated by SUGEF by December 2013}

\begin{tabular}{|l|r|r|}
\hline Period & & $\%$ \\
\hline $1955-1959$ & 5 & 17.2 \\
\hline $1960-1969$ & 13 & 44.8 \\
\hline $1970-1979$ & 7 & 24.1 \\
\hline $1980-1989$ & 2 & 6.9 \\
\hline $1990-1999$ & 2 & 6.9 \\
\hline Total & $\mathbf{2 9}$ & 100.0 \\
\hline
\end{tabular}

Although financial repression was arguably a major driver of the emergence of CUs in Costa Rica, other elements also played a role. Paramount among them was the activity of the United States-based Credit Union National Association (CUNA) in the promotion of credit unions in developing countries. J. Carroll Moody and Gilbert Fite (1971) report that in the 1950s CUNA had already established its World Extension Department (WED), aimed at the expansion of credit unions abroad. The WED was later replaced by CUNA International, an organization that teamed up with a wide array of organizations to foster credit-union growth in developing nations. According to Moody and Fite (1971), by the autumn of 1970 there were 1,333 credit unions in Central America. In 1963, a program established in Costa Rica by CUNA and the United States Agency for International Development (USAID) led to the creation of a network of CUs called FEDECREDITO (a Spanish acronym of the Federación Nacional de Cooperativas de Ahorro y Crédito y Servicios Múltiples). Subsequently, FEDECREDITO teamed up with CUNA and USAID to foster the development of credit unions in Costa Rica. It was behind the creation of 60 of them between 1964 and 1968 (Romero St. Bonnet, 1995; Vega \& Castro, 1988). The Costa Rican government also favoured the establishment of co-operatives, setting up specialized organizations to foster them, such as the Departamento de Fomento de Cooperativas of the Banco Nacional de Costa Rica in 1953, and, 20 years later, the Instituto Nacional de Fomento Cooperativo, and passing legislation with the same purpose (Instituto Nacional de Fomento Cooperativo, 2017).

FEDECREDITO's objectives were to lobby in favour of the affiliated CUs, to seek financing for them, and to give them technical assistance. Mylena Vega and Carlos Castro Valverde (1988) report that by 1988 a crisis almost led FEDECREDITO to close its operations, an outcome that was only averted with the support of USAID. Afterward, FEDECREDITO created several enterprises, including a bank and an agency devoted to trading financial securities. By 1998, the bank that FEDECREDITO owned suffered a bank run, which in turn led to the bankruptcy of FEDECREDITO and its closure. A new organization was created in 1999 called FEDEAC (a Spanish acronym for the Federation of Credit Unions) [FEDEAC, n.d.]. An examination of its 2017 annual report reveals that the organization has more limited objectives than its predecessor. It had just four permanent staff by 2016 and owned assets of less than U.S.\$250,000. Despite its limited 


\section{Rojas, Deschênes, Ramboarisata, \& Leclerc (2018)}

resources, FEDEAC seems to be accomplishing an important task as a lobbyist, provider of technical assistance, and disseminator of information to its CU members (FEDEAC, 2017).

By the mid-1980s, a reform of financial policies began in Costa Rica. These reforms followed a deep economic crisis labelled by Mitchell Seligson and Edward Muller (1987) as "unprecedented" (p. 306). ${ }^{2}$ Austerity measures were implemented, and they were coupled with more long-term reforms of economic policy, intended to promote drastic changes in the external-trade and financial sectors, and the reform of the state apparatus (Clark, 1997; Sandbrook et al., 2007; Sauma \& Trejos, 1999).

Between 1984 and 1987, the caps on banks' portfolios were dismantled for most activities (Lizano, 2004). In 1984, private banks were allowed to mobilize funds from donor agencies that were destined for the private sector, with the guarantee of the Central Bank. The Costa Rica government signed two structural-adjustment loans (SALs) from the World Bank in 1988. Among other things, those loans included an initiative to further the reform of the financial sector. Within the framework of the agreements with the World Bank related to the second SAL, the regulation of financial-sector players was strengthened, leading to the creation of the Auditoría General de Entidades Financieras (AGEF being its Spanish acronym, General Auditor of Financial Entities) that belonged to the Central Bank. The mandate of the new entity included the regulation of all financial institutions, and not only banks (Meoño \& Escoto, 2006). As a consequence of this first wave of reforms, the number of private banks operating in Costa Rica rose from five to 17 from December 1980 to June 1990 (Rojas Herrera, 1994). The reform of the financial sector in Costa Rica was greatly furthered in 1995 by Law No. 7558, which abolished the monopoly of state banks in issuing chequing accounts (García, 2004). Moreover, in the same year, the AGEF was transformed into the Superintendencia General de Entidades Financieras (SUGEF, by its Spanish acronym), with a broader mandate than the purely auditing tasks confided to its predecessor and with greater autonomy from the Central Bank (Villalobos, Sanders, \& De Ruijter, 2003). The reform of the Costa Rican financial sector had direct consequences for credit unions. Law No. 7391 (Regulación de Intermediación Financiera de Organizaciones Cooperativas) was passed in 1994, establishing that the SUGEF would regulate credit unions in the country (Instituto Nacional de Fomento Cooperativo, 2012).

Costa Rican CUs have also been subjected to many pieces of legislation aimed at the regulation of credit unions and cooperative organizations at large (Centro de Estudios y Capacitación Cooperativa, 2017; Instituto Nacional de Fomento Cooperativo, 2012). This legislation dictates that credit unions can only conduct financial intermediation with their own members, who can only be individuals or not-for-profit organizations. Credit unions cannot issue chequing accounts either, nor raise funds in the stock market. However, CUs enjoy a number of fiscal privileges that precede the financial reforms and that the latter had left untouched. Costa Rican CUs do not pay tax on the surpluses of income over expenses (the accounting equivalent of profits in the case of banks and other financial players). Instead, they contribute a percentage of their surpluses to finance public and private organizations created to regulate and promote co-operatives in Costa Rica, a sort of quasi-fiscal burden. Their contribution for this purpose is much lower than the income taxes paid by stateowned commercial banks and private banks. See the appendix for data showing that those financial institutions devoted, respectively, 30.07 percent and 30.40 percent of their earnings to income tax during the years 2008-2016, while CUs only contributed 4.44 percent of their surpluses to fund the agencies that serve them.

In addition to these tax advantages, holders of deposits in private-sector and state-owned commercial banks had to pay an income tax of eight percent on the interest they earned for those deposits, with the financial institutions being obliged to retain the funds and transfer them to the fiscal authorities. Credit unions do not have to do so, giving them an edge, especially in the case of members of credit unions with large investments. However, it is important to highlight that most, if not all, of the above-mentioned tax advantages were implemented by Costa Rican governments well before the mid-1990 


\section{Rojas, Deschênes, Ramboarisata, \& Leclerc (2018)}

reforms, not afterward (Arce, 2006, personal communication, 2016). Thus, their capacity to boost the competitive edge of CUs probably depended on other elements, such as the possibilities that brought about the financial reform itself.

The effects of the reforms on the competitive advantage of credit unions have, to the best of our knowledge, not yet been analyzed in the academic literature in the context of Costa Rica. This article aims to fill that void. To that effect, it asks the question of how the financial reforms of the mid-1990s impacted credit unions in Costa Rica. That research question has guided this inquiry. The topic deserves analysis because it can give important insights that are useful to both the makers of policy and the managers of credit unions. David Cole (1974), in an early criticism of the financial-repression school, contended that reforming the financial sector, in the sense of freeing it to market forces as advocated by Edward Shaw (1973), could be unwarranted if there are no reasonable prospects that reform will serve the general interest. Cole reasoned that financial liberalization could result in increasing the number of financial resources in the economy. However, society at large can only benefit from these additional resources if many competitive financial institutions disperse and regulate power through market forces. Cole (1974) considers the latter outcome unlikely in the real world, because, "Banking is an industry where costs decrease and influence increases with scale, resulting in a strong tendency toward consolidation and oligopoly" (p. 1,348). Athanasios Noulas, Subhash Ray, and Stephen Miller (1990) found empirical evidence in the United States of the presence of economies of scale in the banking industry. Wheelock and Wilson (2011) suggest that credit unions in the United States operated under increasing returns of scale. The fate of credit unions in Costa Rica after the reforms could help policymakers by providing them with evidence concerning the issue raised by Cole. As will be shown later, credit unions were a relatively marginal actor in the financial sector when the 1995 reform took place. If Cole was right, the ability of credit union to gain competitiveness (measured by market share) would be hampered as a consequence of their small scale. If, on the contrary, they proved able to thrive, as compared to Stateowned commercial banks and private-sector banks, the case of researchers advocating financial reform would be supported by empirical evidence.

Problems of governance could also hamper CUs. Jean-Noël Ory, Mireille Jaeger, and Emmanuelle Gurtner (2006) noted that credit unions could be faced with important agency costs stemming from their organizational design. Given the principle of "one member, one vote," regardless of the individual investments, that most CUs apply in their governance, it is not possible for large stockowners to invest in disciplining the management team of a credit union. Moreover, ownership rights in the case of CUs are not alienable, and, therefore, there are no secondary markets where the equity shares could be negotiated, limiting a mechanism to check managerial self-serving behaviour. Ory et al. (2006) also recognize, however, that good governance could also be provided by the product markets, particularly in contexts where the financial industry is highly competitive. Disgruntled CU members could also quit, resulting in the loss of both a client and an equity owner for the CU, a threat that may discipline self-serving top managers. Johnston Birchall (2017) contends that the governance of co-operatives has exhibited some shortcomings. Most notably, their members do not have access to the information that is conveyed by changes in the stock price, which reflect the quality of management of stock-traded companies. Nevertheless, the author stresses that co-operatives could create an organizational design able to overcome these limitations in the governance by fostering relationships between members and the board, managers and the board, and management and employees. In fact, as Birchall (2017) highlights, scholarly research has provided empirical evidence that European co-operative banks can outperform their competitors in all the conventional indicators of efficiency, profitability, and stability. McKinsey and Company (2012) reports that between 2005 and 2010, 47 cooperatives-spanning numerous countries, both industrial and emerging-were able to grow in four sectors, insurance, banking, retail, and agriculture, at nearly the same rate as their 54 stock-traded counterparts, although there was some variation in terms of industry and geographic location. 


\section{Rojas, Deschênes, Ramboarisata, \& Leclerc (2018)}

\section{DATA AND METHODOLOGY}

In order to inquire into the topic under investigation, we compiled accounting information related to CUs and other important players in the financial industry that were likely to be affected by the removal of the policies of financial repression and the emergence of a new regulatory environment in Costa Rica.

The year 1995 was chosen as the vantage point. We believe that our database would have gained substantially if it could have contained data from the years preceding the reforms of the mid-1990s; however, that information is not available to the public.

The new regulatory body of the financial industry in Costa Rica was set up in that year by the new Ley Orgánica del Banco Central de Costa Rica (Law No. 7558). The new regulator, SUGEF, acquired its own governing board and more powers and autonomy than its predecessor, the Auditoría General de Entidades Financieras (AGEF) (García Soto, 2004).

The creation of SUGEF is a major landmark in the development of today's financial system in Costa Rica. Furthermore, the same law ended the monopoly that state-owned banks enjoyed over current accounts. Under certain conditions, private-sector banks were allowed to issue current accounts, a decision that considerably increased their access to new funds (El Financiero, 2014).

The SUGEF started compiling accounting data on the entities that it had regulated since 1995 (data for CUs started to be reported one year later). That database is available to the public on SUGEF's website (www.sugef.fi.cr). It is worth mentioning that SUGEF regulates only open-bond CUs, owning total assets valued at 1,266 million Costa Rican colones or more (SUGEF, 2018), roughly U.S. \$2.3 million, at the exchange rate of 2016 (554.64 colones per U.S. dollar), as reported by the International Monetary Fund (2017). ${ }^{3}$

In order to advance the inquiry, we downloaded information about a number of accounting variables, including total assets (the net of SUGEF's estimates for uncollected receivables), the book value of capital, net income (net surpluses, in the accounting terminology of CUs), and effective taxation for three major types of financial institutions. Those institutions are: the ensemble of the three state-owned commercial banks (Banco Crédito Agrícola de Cartago, Banco de Costa Rica, and Banco Nacional de Costa Rica); the ensemble of private-sector banks; and the ensemble of CUs. The financial sector of Costa Rica comprises financial institutions other than those analyzed in this article. For instance, five non-banking financial enterprises and two banks established by special laws were also regulated by SUGEF, among other financial institutions, by December 2013. Nonetheless, the three types of players scrutinized in this study are by far the most important absorbed more than four-fifths of assets, on average, during the period 1996-2016. In order to take into account the potential influence of the financial crisis of 2008 on the Costa Rican financial system, calculations for the period before it happened, from 1995 to 2007, and the ones after it happened, from 2008 to 2016, are reported separately.

\section{RESULTS AND DISCUSSION}

The data presented in Table 2 show that CUs considerably increased the value of their assets (unadjusted by inflation) during the period under investigation. Data is not adjusted for inflation because this analysis aims at a comparison of the market share of the three types of actors under investigation. The metric used to proxy market share, the percentage of assets held by each type of actor as compared to the financial sector as a whole, would not be altered if the computations were made on an inflation-adjusted or unadjusted basis. 
Rojas, Deschênes, Ramboarisata, \& Leclerc (2018)

\section{Table 2: The evolution of the Costa Rican financial sector, total assets (billions of current Costa Rican colones)}

\begin{tabular}{|l|r|r|r|r|r|r|r|r|r|r|r|r|r|r|r|r|r|r|r|r|r|r|r|}
\hline & 1995 & 1996 & 1997 & 1998 & 1999 & 2000 & 2001 & 2002 & 2003 & 2004 & 2005 & 2006 & 2007 & 2008 & 2009 & 2010 & 2011 & 2012 & 2013 & 2014 & 2015 & 2016 & $\begin{array}{r}1996- \\
2016\end{array}$ \\
\hline
\end{tabular}

Notes: 1) Includes only credit unions that are regulated by SUGEF (assets of 1,151 million Costa Rican colones or more); 2) includes the three state-owned commercial banks: Banco Crédito Agrícola de Cartago, Banco de Costa Rica, and Banco Nacional de Costa Rica; and 3) the financial sector of Costa Rica comprises other players than credit unions, state-owned, and private-sector commercial banks. 


\section{Rojas, Deschênes, Ramboarisata, \& Leclerc (2018)}

Credit unions possessed nearly 42.2 billion Costa Rican colones in 1996, which is 3.7 percent of the nominal value of the assets owned by all institutions in the financial sector. By 2007, CUs exhibited in their balance sheets assets of 747.8 billion Costa Rican colones, or 7.4 percent of the value of assets of the whole financial sector. By 2016, credit unions held roughly 2.9 trillion Costa Rican colones, or 9.9 percent of all assets being held by financial institutions regulated by SUGEF. This, compared to 1996, was almost three times the level in percentage terms.

Private-sector commercial banks also exhibited important growth in market share, although not as fast as that of CUs. In 1995, this type of bank held 173.5 billion Costa Rican colones, 23 percent of total assets of all institutions in the Costa Rican financial sector. By 2007, that figure had risen to 3,005.2 billion, 29.8 percent of financial sector as a whole. Assets owned by private-sector banks represented 32 percent of all assets held by financial players in Costa Rica by 2016.

The gains of both CUs and private-sector banks, in terms of market share, came at the expense of state-owned commercial banks, which lost considerable market share during the period under examination, measured by the percentage of their assets, compared to those of the financial sector. In 1995 the three state-owned banks absorbed 60.8 percent of all assets possessed by the ensemble of players in the financial sector. By 2016 , the figure had dropped to just 39.3 percent. This reduction is even more remarkable than appears at first sight. Deposits from the public are not insured in Costa Rica. In state-owned banks, however, deposits could be covered by the government if it so decides. For example, in June 1994, the government intervened in the Banco Anglo Costarricense, and guaranteed its deposits, at great financial cost. Deposit holders, including potential members of CUs, thus have an incentive to keep their accounts in state-owned banks, where they have a better chance of being reimbursed in case of bankruptcy. ${ }^{4}$

Table 2 reports the percentage change of the value of assets, as compared to the previous year, as well as the arithmetic average of this metric. It is interesting to observe that credit unions grew faster than state-owned banks and private sector banks during the whole period under study (1995-2016), as well as both before and after the financial crisis of 2008. It is also worth highlighting that the three types of financial institutions exhibited slower rates of growth after the financial crisis.

In summary, these findings enable us to address our research question. Even though Costa Rican CUs were born when economic policy emphasized financial repression, the abolition of these restrictions did not have any adverse effects on them. Quite the contrary, they thrived in the new environment. Credit unions in Costa Rica did not seem to be condemned to be marginal players in the financial sectors, being punished for their smaller size, at least during the period under examination, a possibility suggested by Cole (1974). This finding is consistent with results from Ory et al. (2006), who found that CUs and banks owned by CUs in France had fared well over the years 1990-2002, despite the deregulation of the industry that had been taking place in the country. It is also consistent with Surendra Kaushik and Raymond Lopez (1994), who asserted that 15 years after the deregulation of the financial-services industry in the United States, "The state of the credit union industry has never been as bright as it appears to be in the early 1990s" (p. 240). Wheeler and Wilson (2011) present evidence as well that CUs in the United States have grown fast since the 1980s.

This explanation of the enhanced competitive advantage of Costa Rican CUs after the financial reform is multipronged. First, CUs are not allowed to raise capitals in the stock markets, as Ory et al. (2006) point out, which means that they can only sustain their growth by means of retained profits (Goddard, McKillop, \& Wilson, 2002). ${ }^{5}$ One way to escape this constraint is to finance growth (new loans and other assets) by increasing liabilities. Because of the fundamental accounting equation, this would imply a lower capital-to-assets ratio (we use the terms "capital" and "equity" interchangeably). Second, higher capital-to-assets ratios would signal overcautious management, which can hamper growth (Goddard et al., 2002). Third, Costa Rica never implemented any type of deposit insurance, even for small investment amounts. In this context, members of a CU cannot know in advance if they can get back their entire investments in the case of liqui- 


\section{Rojas, Deschênes, Ramboarisata, \& Leclerc (2018)}

dation. This latter event was not unusual before and even after the financial reforms of $1995 .{ }^{6}$ In order to be prepared for any economic turbulence or possible "bank runs," managers of CUs had an incentive to hold large reserves. The strong precautionary regulation, which arguably only arrived with SUGEF, allowed them to reduce capital reserves because the new regulation reduced the asymmetry of information ${ }^{7}$ between the managers of CUs, on the one hand, and actual and potential members, on the other hand. This article argues that the enhanced monitoring of financial institutions brought about by SUGEF improved the quality and quantity of financial information on CUs available to the public, thus reducing the level of the asymmetry of information. One can view the high levels of capital-to-assets ratios that managers of CUs maintained before the creation of SUGEF as a sign to members and potential members of the financial health of the organizations that they ran, and of their ability to deal with eventual contagion crises. Arguably, such signs (strong capital reserves) were less needed once better regulation had been implemented, because members and potential members of CUs could have access to better information on the financial health and economic prospects of these organizations.

This study's data supports this notion. Table 3 suggests that CUs had fuelled their growth by increasing their leverage, which consequently implies a lower capital-to-assets ratio. In 1996, the book value of capital represented 30.1 percent of assets owned by the ensemble of CUs. By 2007, the corresponding figure had descended to 17.8 percent. It ended up at 17.9 percent in 2016. In the same table, it is reported the non-weighted average of the ratio of equity to total assets (in percentage). As Table 3 shows, the average of this metric was 24.2 percent for the years 1996-2016, a clear reduction compared to the first year in our database. Moreover, the non-weighted average of yearly changes in the case of CUs was minus 2.4 percent, as the ratio increments were outmatched by reductions throughout the period. A similar picture emerges from private-sector banks. In 1995, equity represented 15.3 percent of the value of total assets. By 2007, the corresponding figure was 8.9 percent. In 2016, it had risen slightly to 10.1 percent, which is still well below the 1995 figure. The non-weighted average was 10.7 percent throughout the period, and the average of yearly changes was negative as well. State-owned banks also exhibited a modest increase in the ratio, from 8.1 percent in 1995 to 9.8 percent in 2016. The average year-to-year increment is positive. In short, financial institutions that experienced growth in their market share also exhibited a reduction in the ratio of equity to total assets.

This analysis takes into account the impact of the financial crisis of 2008. The last three columns of Table 3 show that CUs reduced the ratio of capital to assets faster than private-sector banks, while state-owned commercial banks increased this metric before the beginning of the financial crisis. After the financial crisis, the three players exhibited an increase in this metric, including CUs. However, the latter's ratio increased at a much slower pace than the other two types of financial institutions. It is interesting to note that CUs gained market share after the crisis, albeit at a much slower pace than before. Although this explanation sheds light on the enhanced ability of CUs to compete with other players, as the concluding section of this article explores, this explanation is certainly not exhaustive, and other avenues for future research into this topic are, indeed, conceivable.

It is important to also note that if greater leverage is a source of competitiveness, CUs may still exploit that advantage for some time. By the end of 2016, their ratio of equity to total assets was still much higher (17.9\%) than the corresponding figure for the other two players ( $9.8 \%$ for state-owned commercial banks and $10.1 \%$ for private-sector banks). Although managers of Costa Rican CUs should consider further reducing the ratio of capital to assets to encourage future growth, this strategy also has its limitations. First, if the regulation was effective in reducing the asymmetry of information between the management of CUs and the membership base, allowing the CU management to increase leverage to finance its assets, it is also possible that the regulatory environment is an imperfect mechanism to convey information concerning the financial health of the CU. In the absence of a system of deposit insurance, Costa Rican CUs still had to exhibit relatively high levels of capital to assets in their balance sheets, in order to be able to face future economic turbulence and systemic threats. Second, it has been reported in the press that loan portfolios of CUs are not very diversified, with consumption 
Rojas, Deschênes, Ramboarisata, \& Leclerc (2018)

Table 3. Capital (equity) as a percentage of total assets, Costa Rican financial sector

\begin{tabular}{|c|c|c|c|c|c|c|c|c|c|c|c|c|c|c|c|c|c|c|c|c|c|c|c|c|c|}
\hline & 1995 & 1996 & 1997 & 1998 & 1999 & 2000 & 2001 & 2002 & 2003 & 2004 & 2005 & 2006 & 2007 & 2008 & 2009 & 2010 & 2011 & 2012 & 2013 & 2014 & 2015 & 2016 & $\begin{array}{l}1996- \\
2016\end{array}$ & $\begin{array}{l}1996- \\
2007\end{array}$ & $\begin{array}{l}2008- \\
2016\end{array}$ \\
\hline \multicolumn{26}{|l|}{ Credit unions ${ }^{1}$} \\
\hline Value of capital ${ }^{2}$ & n.a. & 12.7 & 16.3 & 19.3 & 19.1 & 23.0 & 27.9 & 35.5 & 44.7 & 57.5 & 76.3 & 97.7 & 133.3 & 172.2 & 207.2 & 236.4 & 282.5 & 328.4 & 381.9 & 434.3 & 486.9 & 525.4 & & & \\
\hline $\begin{array}{l}\text { Capital as a \% of } \\
\text { total assets }\end{array}$ & & 30.1 & 29.7 & 33.2 & 33.5 & 33.1 & 31.0 & 29.3 & 27.4 & 25.1 & 21.8 & 19.3 & 17.8 & 18.4 & 19.1 & 21.0 & 21.3 & 20.7 & 19.7 & 19.3 & 18.5 & 17.9 & 24.2 & 27.6 & 19.6 \\
\hline $\begin{array}{l}\text { \% change in capital } \\
\text { to assets ratio }\end{array}$ & & & -1.3 & 11.9 & 0.7 & -0.9 & -6.5 & -5.4 & -6.6 & -8.6 & -12.8 & -11.4 & -7.9 & 3.0 & 4.1 & 9.8 & 1.5 & -2.9 & -4.6 & -2.1 & -4.2 & -3.1 & -2.4 & -4.4 & 0.2 \\
\hline \multirow{2}{*}{\multicolumn{26}{|c|}{ State-owned banks ${ }^{3}$}} \\
\hline & & & & & & & & & & & & & & & & & & & & & & & & & \\
\hline Value of capital ${ }^{2}$ & 37.1 & 39.3 & 53.4 & 62.4 & 77.4 & 91.6 & 112.1 & 125.5 & 180.8 & 214.8 & 292.9 & 378.4 & 421.1 & 555.9 & 622.2 & 673.8 & 729.6 & 815.0 & 878.4 & 943.5 & 1033.3 & 1139.3 & & & \\
\hline $\begin{array}{l}\text { Capital as a \% of } \\
\text { total assets }\end{array}$ & 8.1 & 5.4 & 6.8 & 6.5 & 7.0 & 7.1 & 8.2 & 7.8 & 9.6 & 8.2 & 9.3 & 9.9 & 9.3 & 10.5 & 10.3 & 10.4 & 10.5 & 10.2 & 9.5 & 9.3 & 9.6 & 9.8 & 8.8 & 7.9 & 10.0 \\
\hline $\begin{array}{l}\% \text { change in capital } \\
\text { to assets ratio }\end{array}$ & & -33.5 & 27.2 & -5.0 & 8.4 & 0.8 & 15.1 & -4.9 & 23.4 & -14.6 & 13.3 & 6.5 & -6.0 & 12.7 & -1.8 & 1.2 & 0.8 & -3.0 & -6.8 & -2.5 & 3.4 & 2.0 & 1.8 & 2.6 & 0.7 \\
\hline \multicolumn{25}{|l|}{ Private-sector banks } & \\
\hline Value of capital' & 26.6 & 31.3 & 35.5 & 43.4 & 59.4 & 71.4 & 84.6 & 102.2 & 120.6 & 135.3 & 166.9 & 226.1 & 266.7 & 405.0 & 453.6 & 491.9 & 545.2 & 600.7 & 670.7 & 770.0 & 871.3 & 961.4 & & & \\
\hline $\begin{array}{l}\text { Capital as a \% of } \\
\text { total assets }\end{array}$ & 15.3 & 14.7 & 11.9 & 10.5 & 12.4 & 10.8 & 10.2 & 10.0 & 9.3 & 8.7 & 8.4 & 9.2 & 8.9 & 9.5 & 10.4 & 11.4 & 11.2 & 11.0 & 10.9 & 10.5 & 10.4 & 10.1 & 10.7 & 10.8 & 10.6 \\
\hline $\begin{array}{l}\text { \% change in capital } \\
\text { to assets ratio }\end{array}$ & & -4.2 & -18.7 & -12.5 & 18.3 & -12.8 & -5.5 & -1.5 & -7.4 & -6.2 & -3.2 & 8.8 & -3.2 & 7.0 & 9.4 & 9.3 & -1.6 & -1.6 & -0.4 & -3.7 & -1.7 & -2.7 & -1.6 & -4.0 & 1.6 \\
\hline & & & & & & & & & & & & & & & & & & & & & & & & & \\
\hline \multicolumn{26}{|l|}{ Total, financial sector ${ }^{4}$} \\
\hline Value of capital ${ }^{2}$ & 115.4 & 139.7 & 177.72 & 215.7 & 265.6 & 318.6 & 378.45 & 465.7 & 583.7 & 685.2 & 876.5 & $1,106.6$ & $1,292.1$ & $1,637.0$ & $1,874.6$ & $2,084.8$ & $2,346.0$ & $2,658.7$ & $2,979.1$ & $3,317.8$ & $3,704.3$ & $4,083.5$ & & & \\
\hline $\begin{array}{l}\text { Capital as a \% of } \\
\text { total assets }\end{array}$ & 15.3 & 12.4 & 13.4 & 12.3 & 13.3 & 13.0 & 13.6 & 13.7 & 14.2 & 12.8 & 13.1 & 13.4 & 12.8 & 13.0 & 13.6 & 14.4 & 14.6 & 14.4 & 14.1 & 13.7 & 13.8 & 13.8 & 13.6 & 13.3 & 13.9 \\
\hline $\begin{array}{l}\% \text { change in capital } \\
\text { to assets ratio }\end{array}$ & & -18.8 & 8.1 & -8.4 & 8.5 & -2.3 & 4.2 & 1.0 & 3.6 & -9.6 & 2.3 & 2.3 & -4.6 & 1.2 & 4.6 & 6.2 & 1.5 & -1.5 & -2.1 & -2.5 & 0.6 & -0.4 & -0.3 & -1.1 & 0.8 \\
\hline
\end{tabular}

Notes: 1) Includes only credit unions that are regulated by SUGEF (assets of 1.266 billion or more Costa Rican colones; 2) figures stated in billion current Costa Rican colones; 3 ) includes the three stateowned commercial banks: Blanco Crédito Agricola de Cartago, Banco de Costa Rica, and Banco Naciional de Costa Rica 


\section{Rojas, Deschênes, Ramboarisata, \& Leclerc (2018)}

credit taking a large proportion of it. There are even CUs whose loan portfolio comprises credit for consumption exclusively (Leitón, 2017). Under these circumstances, it is possible that Costa Rican CUs should set their ratio of capital to assets at levels that are higher than those of financial institutions with a more diversified portfolio.

\section{CONCLUDING REMARKS}

This article argues that CUs were created as a collective response to the lack of credit for individuals arising from the environment of financial repression that predominated in Costa Rica from the 1950s onwards, and started to be dismantled by the mid-1980s (Lizano, 2004). By December 2013, roughly 70 percent of the CUs supervised by SUGEF had been incoporated by the 1960s or 1970s. Also the emergence of CUs was also considerably furthered by governmental policies intended to promote cooperatives and technical assistance from private and public agencies, some of them from abroad. CUs consolidated during the times of financial repression because they could reach an underserved market, namely, consumption credit. They presumably benefited as well from the absence of private-sector commercial banks in Costa Rica, for these only arrived later, with the removal of financial repression.

As businesses whose existence is arguably linked to the existence of financial repression in Costa Rica, CUs could have suffered a serious backlash after the reform of the policies regulating the operation of financial markets in Costa Rica. However, decades of financial repression might have harmed state-owned commercial banks to the point that they were not able to take full advantage of the liberalization of financial markets. Moreover, the stronger regulation brought about by the reforms initiated in the 1980s, which moved away from the interventionist policies of the past toward a neutral regulation that ensured, for instance, the monitoring of solvency of financial intermediaries, could have helped other financial institutions than state-owned banks. The latter, being backed by governmental agencies in the case of bankruptcies or crises, had presumably less to gain from better-quality supervision.

The data from this study show that CUs saw their market share almost triple during the period under study, measured by the ratio of the percentage of the value of total assets owned by the CUs compared to value of total assets owned by the ensemble of the players in the financial sector in Costa Rica. Private-sector banks also exhibited a gain, although a more modest one than the CUs had experienced. These saw their market share rise from 23 percent to 32.1 percent during the period from 1995-2016. State-owned banks lost considerable market share during that period. They possessed almost 61 percent of the market share in 1995, but this fell to roughly 39.3 percent in 2016. In fact if this trend continues, CUs might become a major player in the financial market of Costa Rica, well beyond the marginal role they played nearly two decades ago.

This article argues that the financial reforms of 1995 enhanced the quality of the regulation of financial institutions. Those reforms, moreover, brought about the regulation of CUs by the financial watchdog for the first time (Huaylupo, 2003). In view of our analysis, the new regulatory environment allowed CUs to reduce their capital reserves. Credit unions exhibited a very high ratio of capital to assets, as observed at the beginning of the period under investigation. This study concludes that CUs had fuelled their growth by substantially reducing the ratio of equity to total-assets owned, a trend also present in the case of private-sector banks. It is worth mentioning that, despite the increased risk emanating from a diminished ratio of equity to total assets, CUs seem to have been more risk-averse than the other two players. In fact, equity financed almost 20 percent of CUs' total assets, roughly twice the percentage of state-owned banks and private-sector banks. If increased leverage is a way of spurring growth, then CUs still have a way to go.

Of interest to researchers, is that these findings could support the view that financial reform does not necessarily harm CUs or smaller actors in the financial market, which can also thrive in a freer economic environment. Regulators could also gain from these insights. The findings suggest that a reduction in the ratio of capital to assets has fuelled the growth 


\section{Rojas, Deschênes, Ramboarisata, \& Leclerc (2018)}

of CUs. Of course, this strategy may increase risks. Still, regulators could look at the specifics of particular types of portfolio in the CUs to ascertain the possibilities of designing appropriate limits for that indicator.

This explanation of the enhanced ability of CUs to outcompete other players in the financial markets is certainly not exhaustive. Credit unions might enjoy an informational advantage compared to other players in the financial sector in Costa Rica. This proposition can be tested empirically, albeit in an indirect manner. For instance, it should be possible to ascertain if CUs treated certain type of credit more rapidly, or at a lesser cost, compared to other financial institutions. This task, however, would involve data that we do not have access to. Goth, McKillop, and Wilson (2012) report that mergers have fuelled the growth of CUs in the United States and Canada. There is evidence that mergers among CUs also occurred in the Costa Rican context. Between 1996 and 2016, eight mergers were reported by SUGEF (Alvarez, 2017, personal communication). Four CUs were responsible for them, and five of the mergers were conducted by a single CU, Coopealianza. Apparently, smaller or less efficient CUs were absorbed by their larger or more efficient counterparts, thus benefiting from economies of scope and scale. Based on the above-mentioned data, it is possible that, unlike in the cases of the United States and Canada, growth in the Costa Rican context had a rather limited impact on the growth of the surviving entities. However, this research design cannot offer a definitive response to the question of how important mergers were as drivers of growth. Thus, future researchers could examine the role that mergers might have had in the rapid growth of CUs in Costa Rica, using an appropriate design for that purpose.

Finally, it is possible to argue that CUs, having started at the lower end of the spectrum in terms of size, had more room to grow as compared to state-owned banks and private banks. The question of how the size of organizations could impact their growth patterns has been a subject of debate for scholars going back to the publication of Robert Gibrat (1931), who contended that the size of firms is unrelated to their growth. The jury is still out on Gibrat's assertion. For instance, Johannes Van Biesebroeck (2005) provided evidence that size matters for growth in the context of manufacturing firms in nine sub-Saharan countries, while Erik Stam (2010) reported a number of studies contradicting Gibrat's proposition on the independence of firm size and growth. The topic clearly deserves attention in the context of Costa Rican CUs. However, in order to shed light on the possibility that the size of an organization could have a distinct impact on growth, it is necessary to employ an entirely different approach to the one implemented here. Although such a program of research could be fruitful, it is certainly beyond the scope of this study's methodology.

\section{NOTES}

1. See Werner Baer (1972) for a detailed exposure of the implementation of ISI. He also provides an early criticism of the policy, stressing its shortcomings.

2. According to Mitchell Seligson and Edward Muller (1987), the foreign debt grew from U.S. $\$ 840$ million in 1978 to U.S. $\$ 3$ billion in 1982, approaching the value of the entire gross national product of that year. Monetary reserves that were 358 million in 1978 became negative in 1982. Inflation, which was historically single digit in Costa Rica, rose to 108 percent in 1981-1982, measured by the wholesale price index.

3. It has recently been reported that SUGEF will soon start supervising CUs with assets under 1,266 million colones. These smaller CUs, offering membership to specific groups of workers, were regulated by an agency of the Costa Rican co-operative movement. According to estimates, about 38 such CUs exist in Costa Rica (Arias, 2018).

4. The Costa Rican government intervened in the Banco Anglo Costarricense, a state-owned bank, after the detection of abnormal transactions. The government announced full coverage of its deposits. Despite this, total deposits fell by one-third during the first three months of the intervention, when the Central Bank of Costa Rica (BCCR in its Spanish acronym) made payments to investors. The Banco Anglo Costarricense was liquidated in September 1994 and the remaining deposits were transferred to other state-owned commercial banks, while the BCCR continued supporting withdrawals in the recipient banks. By the end of the year, it had extended financial assistance equivalent to 3.5 percent of the gross domestic product. Half of this sum was paid back to the BCCR by the government with bonds (Jácome, 2008).

5. New members must contribute to the capital of the CUs, but this is likely a very limited way of increasing the resources available to finance additional assets because these contributions tend to be small. For instance, prospective members of Coocique (n.d.), a large CU, must currently pay a single fee of 1,000 Costa Rican colones for the processing of their application and contribute 7,000 Costa Rican colones to the 


\section{Rojas, Deschênes, Ramboarisata, \& Leclerc (2018)}

capital of the CU. Both payments together are less than U.S. $\$ 15$, as of November 11, 2018. Coopeservidores (n.d.), another large CU, requires a one-time contribution to capital of 5,000 colones to become a new member. Those amounts could vary from one $\mathrm{CU}$ to another, because they depend on the bylaws of each organization. Moreover, the latter can be modified at any moment if the board of directors so decides (Peraza, 2018, personal communication).

6. Juan Huaylupo (2003) reports the liquidation of two banks owned by the cooperative sector during the late 1990s. In 2010, Coopemex, a large CU, also required intervention. It was liquidated one year later (Arias, 2011).

7. See George Akerlof (1970) and Michael Spence (1973) for a thorough discussion on the impact of information asymmetry on the functioning of markets.

\section{REFERENCES}

Adams, D.W. (1971). Agricultural credit in Latin America: A critical review of external funding policy. American Journal of Agricultural Economics, 53(2), 163-172.

Akerlof, G.A. (1970). The market for "lemons": Quality uncertainty and the market mechanism. The Quarterly Journal of Economics, 84(3), 488-500.

Arce Monge, J. (2006). Reformas financieras en Costa Rica para una banca competitiva y sólida. Universidad Estatal a Distancia, Sistema de Estudios de Posgrado, Escuela de Ciencias de la Administración. URL: http://repositorio.uned.ac.cr/reuned/bitstream/120809/818/1/Ensayo_Reforma_Financiera_en_CR_para_una BBanca_competitiva.pdf/ [June 15, 2016].

Arias, J.P. (2011). Concluyó intervención de Coopemex. URL: http://www.nacion.com/archivo/Concluyo-intervencion -Coopemex_0_1178082190.html/ [October 17, 2017].

Arias J.P. (2018). Supervisión de cooperativas ya no quedará solo a merced del Infocoop. URL: https://www.crhoy.com leconomia/supervision-de-cooperativas-ya-no-quedara-solo-a-merced-del-infocoop/ [June 28, 2018].

Baer, W. (1972). Import substitution and industrialization in Latin America: Experiences and interpretations. Latin America Research Review, 7(1), 95-122.

Birchall, J. (2017). The governance of large co-operative businesses. Co-operatives UK. URL: https://www.ica.coop /sites/default/files/publication-files/governance-report2017coops-ukfinalweb-1823508697.pdf [November 11, 2018].

Camacho Mejía, E. (1994). Eficiencia de los bancos. In C. González Vega \& E. Camacho Mejía (Eds.), Regulación, competencia y eficiencia en la banca costarricense (pp. 105-140), San José, CR: Academia de Centroamérica.

Camacho Mejía, E, \& González-Vega, C. (1994). Estructura, regulación y supervisión de la banca'. In C. González Vega \& E. Camacho Mejía (Eds.), Regulación, competencia y eficiencia en la banca costarricense (pp. 375-432). San José, CR: Academia de Centroamérica.

Centro de Estudios y Capacitación Cooperativa. (2017). Actualización en derecho cooperativo. URL: http:// coopebanacio.fi.cr/educacion/pdf/Derecho_Cooperativo.pdf [July 18, 2018].

Cerdas, A.M., \& Melegatti, C. (2014). El Sistema financiero en los últimos años: El sistema de pagos. San José, CR: Academia de Centroamérica.

Clark, M.A. (1997). Transnational alliances and development policy in Latin America: Non-traditional export promotion in Costa Rica. Latin America Research Review, 32(2), 71-97.

Cole, D.C. (1974). Financial deepening in economic development by Edward S. Shaw. The Journal of Finance, 29(4), 1342-1348.

Coocique. (n.d.). Requisitos para asociarse. URL: https://coocique.fi.cr/?page_id=1367 [November 11, 2018]. Coopesevidores. (n.d.). Afiliese a la cooperativa. URL: https://www.coopeservidores.fi.cr/es/afiliese [November 11, 2018].

El Financiero. (2014). Apertura de cuentas corrientes dinamizó la banca. URL: http://www.elfinancierocr.com leconomia-y-politica/Hitos-Apertura_cuentas_corrientes-Eduardo_Lizano_0_259174125.html/ [June 15, 2016]. FEDEAC. (n.d.). Federación de Cooperativas de Ahorro y Crédito de Costa Rica. URL: http://ecgcooperativegroups .blogspot.com/2013/11/federacion-de-cooperativas-de-ahorro-y.html [November 6, 2018]. 


\section{Rojas, Deschênes, Ramboarisata, \& Leclerc (2018)}

FEDEAC. (2017). Informe de labores 2017. URL: http://fedeac.com/wp-content/uploads//informelabores-1.pdf [November 6, 2018].

Franklin, C.C. (1998). Riding the wave: The domestic and international sources of Costa Rican democracy [PhD dissertation]. Pittsburgh, PA: University of Pittsburgh.

García Soto, R. (2004). Moneda, banca y política monetaria. San José, CR: Editorial Universidad Estatal a Distancia. Gibrat, R. (1931). Les inegalités économiques. Paris, FR: Sirey.

Goddard, J.A., McKillop, D.G., \& Wilson, J.O.S. (2002). The growth of US credit unions. Journal of Banking and Finance, 26(12), 2327-2356.

González-Vega, C. (1990). Políticas de intermediación financiera en Costa Rica: Cuatro décadas de evolución. Economics and Sociology Occasional Paper No. 1718. Columbus, OH: Ohio State University. URL: https://kb.osu.edu/bitstream/handle/1811/66227/CFAES_ESO_1718.pdf?sequence=1 [May 12, 2018].

Goth, P., McKillop, D., \& Wilson, J. (2012). Corporate governance in Canadian and US credit unions. Credit Union Central of Canada and Filene Research Institute. URL: https://www.utahscreditunions.org/vendors/images 1274_Corp_Governance.pdf [November 11, 2018].

Huaylupo Alcázar, J.A. (2003). Las cooperativas en Costa Rica. URL: http://unpan1.un.org/intradoc/groups/public /documents/icap/unpan033284.pdf/ [October 18, 2017].

Instituto Nacional de Fomento Cooperativo. (2012). Ley 4179 de Asociaciones Cooperativas y Creación del INFOCOOP y Otras Normas Conexas. URL: http://www.infocoop.go.cr/cooperativismo/legislacion/ley_4179 _conexas.pdf/ [October 12, 2017].

Instituto Nacional de Fomento Cooperativo. (2017). Historia del cooperativismo en Costa Rica. URL: http://www .infocoop.go.cr/conozcanos/linea_tiempo.html/ [May 10, 2017].

International Monetary Fund. (2017). International financial statistics yearbook. URL: https://www.imf.org/en/Data [April 22, 2018].

Jácome, L. (2018). Central bank involvement in banking crises in Latin America. International Monetary Fund, IMF Working Papers WP 08/135. URL: https://www.imf.org/external/pubs/tt/wp/2008/wp08135.pdf/ [August 15, 2016].

Kaushik, S.K., \& Lopez, R. (1994). The structure and growth of the credit union industry in the United States: Meeting challenges of the market. The American Journal of Economics and Sociology, 53(2), 219-243.

Leitón, P. (2017). Cooperativas se concentran en préstamos para consumo. URL: http://www.nacion.com/economia /finanzas/Cooperativas-concentran-prestamos-consumo_0_1638036198.html/ [October 15, 2017].

Lizano, E. (2004). Escritos sobre reforma financiera. San José, CR: Academia de Centroamérica.

McKinnon, R. (1973). Money and capital in economic development. Washington, DC: The Brookings Institution. McKinsey and Company. (2012). McKinsey on cooperatives. URL: http://bccm.coop/wp/wp-content/uploads/2015/03 IMcK_on_Cooperatives-Full_issue.pdf [November 20, 2018].

Meoño, R., \& Escoto, R. (2006). Operaciones bursátiles. San José, CR: Editorial Universidad Estatal a Distancia.

Moody, J.C., \& Fite, G.C. (1971). The credit union movement: Origins and development, 1850-1970. Lincoln, NE: University of Nebraska Press.

Noulas, A.G., Ray, S.C., \& Miller, S.M. (1990). Returns to scale and input substitution for large U.S. banks. Journal of Money, Credit and Banking, 22(1), 94-108.

Ory, J.N., Jaeger, M., \& Gurtner, E.W. (2006). La banque à forme coopérative peut-elle soutenir durablement la compétition avec la banque SA? Finance Contrôle Stratégie, 9(2), 121-157.

Romero St. Bonnet, M.C. (1995). Del reformismo cooperativo al cooperativismo empresario. San José, CR: Escuela de Trabajo Social, Universidad de Costa Rica. URL: http://www.ts.ucr.ac.cr/binarios/docente/pd-000015.pdf [July 23, 2018]. 


\section{Rojas, Deschênes, Ramboarisata, \& Leclerc (2018)}

Rojas Herrera, M. (1994). Competencia por clientes en la banca. In C. González Vega \& E. Camacho Mejía (Eds.), Regulación, competencia y eficiencia en la banca costarricense. (pp. 189-222). San José, CR: Academia de Centroamérica.

Sánchez Boza, L.R., \& Mayorga Acuña, L.F. (1988). Colección de leyes y decretos y jurisprudencia administrativa sobre cooperativismo en Costa Rica. Vol. II. San José, CR: Editorial Universidad Estatal a Distancia.

Sandbrook, R., Edelman, M., Heller, P., \& Teichman, J. (2007). Social democracy in the global periphery. Origins, challenges, prospects. Cambridge, UK: Cambridge University Press.

Sauma, P., \& Trejos, J.D. (1999). Costa Rica. In E. Ganuza, A. León, \& P. Sauma (Eds.), Gasto público en servicios sociales básicos en América Latina y el Caribe. Análisis desde la perspectiva 20/20 (pp. 336-398). URL: https://www.cepal.org/publicaciones/xml/8/4648/indice.htm [June 28, 2018].

Seligson, M.A., \& Mueller, E.N. (1987). Democratic stability and economic crisis: Costa Rica, 1978-1983. International Studies Quarterly, 31, 301-326.

Shaw, E.S. (1973). Financial deepening in economic development. New York, NY: Oxford University Press.

Spence, M. (1973). Job market signaling. The Quarterly Journal of Economics, 87(3), 355-374.

Stam, E. (2010). Growth beyond Gibrat: Firm growth processes and strategies. Small Business Economics, 35, 129135. doi: 10.1007/s11187-010-9294-3

Superintendencia General de Entidades Financieras. (2018). Informe al público. Entidades supervisadas por la SUGEF. URL: https://www.sugef.fi.cr/publicaciones/listado_entidades_sujetas_fiscalizacion/2017/01-\%20Lista \%20de\%20entidades\%20al\%2010-03-2017.pdf [July 1, 2018].

Superintendencia General de Entidades Financieras. (n.d.). SUGEF. www.sugef.fi.cr

Van Biesebroeck, J. (2005). Firm size matters: Growth and productivity growth in African manufacturing. Economic Development and Cultural Change, 53(3), 545-583.

Vega, M., \& Castro, C. (1988). Panorama del desarrollo cooperativo en Costa Rica, vol. 2. San José, CR: Editorial Universidad Estatal a Distancia.

Villalobos, I., Sanders, A., \& De Ruijter De Wildt, M. (2003). Microfinanzas en Centroamérica: Ios avances y desafíos. Santiago, CL: CEPAL.

Wheelock, D.C., \& Wilson, P.W. (2011). Are credit unions too small? The Review of Economics and Statistics, 93(4), 1343-1359.

World Council of Credit Unions. (2016). Statistical report. Credit unions worldwide. URL: http://www.woccu.org/impact Iglobal_reach/statreport/ [October 20, 2017].

\section{ABOUT THE AUTHORS / LES AUTEURS}

Miguel Rojas is Associate Professor of Finance in the Accounting Department at the Université de Moncton. Email: miguel.rojas@umoncton.ca .

Sébastien Deschênes is Dean of the Business School and Professor of Accounting at the Université de Moncton. Email: sebastien.deschenes@umoncton.ca .

Lovasoa Ramboarisata is Associate Professor of Strategy, Social, and Environmental Responsibility at the Université du Québec à Montréal. Email: ramboarisata.lovasoa@uquam.ca .

André Leclerc is Professor of Economics at the Université de Moncton. Email: andre.leclerc@umoncton.ca . 
Rojas, Deschênes, Ramboarisata, \& Leclerc (2018)

\section{APPENDIX}

Taxes and other forms of quasi-taxation as a percentage of earnings (surplus in the case of CUs): Costa Rican financial sector

\begin{tabular}{|c|c|c|c|c|c|c|c|c|c|c|c|c|c|c|c|c|c|c|c|c|c|c|c|c|c|}
\hline & 1995 & |1996 & 1997 & 1998 & 1999 & 2000 & 2001 & 2002 & 2003 & 2004 & 2005 & 2006 & 2007 & 2008 & 2009 & 2010 & 2011 & 2012 & 2013 & 2014 & 2015 & 2016 & \begin{tabular}{|l|}
$1995-$ \\
2016
\end{tabular} & $\begin{array}{l}1995- \\
2007\end{array}$ & $\begin{array}{l}2008- \\
2016\end{array}$ \\
\hline \multicolumn{26}{|l|}{ Credit unions $^{1}$} \\
\hline $\begin{array}{l}\text { Taxes and other forms } \\
\text { of quasi-taxation }{ }^{2}\end{array}$ & n.a. & 0.12 & 0.04 & 0.05 & 0.07 & 0.07 & 0.03 & 0.15 & 0.05 & 0.08 & 0.15 & 0.30 & 0.89 & 0.90 & 0.80 & 1.07 & 1.31 & 1.48 & 1.61 & 1.82 & 1.78 & 1.68 & 0.69 & 0.17 & 1.38 \\
\hline$\%$ of surplus & & 8.1 & 2.2 & 2.3 & 3.7 & 3.2 & 1.0 & 3.5 & 1.0 & 1.2 & 1.5 & 2.5 & 4.3 & 3.8 & 4.9 & 4.3 & 4.4 & 4.5 & 4.5 & 4.7 & 4.5 & 4.3 & 3.55 & 2.89 & 4.44 \\
\hline & & & & & & & & & & & & & & & & & & & & & & & & & \\
\hline \multicolumn{26}{|l|}{ State-owned banks ${ }^{3}$} \\
\hline $\begin{array}{l}\text { Taxes and other forms } \\
\text { of quasi-taxation² }\end{array}$ & 0.5 & 0.0 & 0.0 & 0.0 & 0.1 & 2.6 & 3.0 & 2.4 & 2.5 & 7.1 & 9.0 & 17.2 & 31.4 & 41.7 & 21.8 & 26.6 & 26.0 & 20.2 & 13.1 & 38.5 & 33.8 & 55.6 & 16.05 & 5.83 & 30.81 \\
\hline$\%$ of earnings & 17.9 & 0.0 & 0.0 & 0.0 & 0.6 & 15.7 & $\mid 14.4$ & 14.0 & 8.1 & 16.5 & 14.4 & 20.8 & 31.5 & 33.8 & 29.4 & 31.9 & 31.2 & 18.9 & 18.7 & 38.6 & 34.0 & 34.2 & 19.29 & 11.83 & 30.07 \\
\hline & & & & & & & & & & & & & & & & & & & & & & & & & \\
\hline \multicolumn{26}{|l|}{ Private-sector banks } \\
\hline $\begin{array}{l}\text { Taxes and other forms } \\
\text { of quasi-taxation }\end{array}$ & 0.4 & 0.3 & 0.6 & 0.6 & 0.8 & 1 & 1.2 & 1.5 & 1.9 & 3.9 & 7 & 9.4 & 11.5 & 17.6 & 15.6 & 15.3 & 19.7 & 29.2 & 26.8 & 41.6 & 32.4 & 40.6 & 12.68 & 3.08 & 26.54 \\
\hline$\%$ of earnings & 8.7 & 7.7 & 12.5 & 60.0 & 14.5 & 10.2 & 9.2 & 8.4 & 8.6 & 16.1 & 16.6 & 18.7 & 34.1 & 24.9 & 28.1 & 35.4 & 30.2 & 31.8 & 29.6 & 33.3 & 29.8 & 30.5 & 22.68 & 17.34 & 30.40 \\
\hline \multicolumn{26}{|l|}{ Total. financial sector ${ }^{4}$} \\
\hline $\begin{array}{l}\text { Taxes and other forms } \\
\text { of quasi-taxation }{ }^{2}\end{array}$ & 0.9 & 0.5 & 0.6 & 0.7 & 0.9 & 3.8 & 5.0 & 5.5 & 4.6 & 12.1 & 18.5 & 30.7 & 51.6 & 69.7 & 44.3 & 51.1 & 63.2 & 62.9 & 47.0 & 92.3 & 83.7 & 115.0 & 34.75 & 10.42 & 69.91 \\
\hline$\%$ of surplus/earnings & 7.1 & 3.2 & 2.5 & 4.4 & 2.7 & 9.2 & 9.1 & 8.8 & 5.5 & 11.4 & 11.9 & 16.3 & 24.8 & 25.1 & 22.4 & 23.7 & 23.7 & 19.7 & 16.9 & 26.3 & 24.7 & 25.1 & 14.75 & 8.99 & 23.07 \\
\hline
\end{tabular}

Notes: 1) Includes only credit unions that are regulated by SUGEF (assets of 1.266 billion Costa Rican colones or more); 2) stated in billion Costa Rican colones; 3 ) includes the three state-owned commercial banks: Banco Crédito Agrícola de Cartago, Banco de Costa Rica, and Banco Nacional de Costa Rica; 4) the financial sector of Costa Rica comprises other players than credit unions, state-owned, and private-sector banks 